\title{
INTEGRATED EVALUATION OF SOIL QUALITY AFTER THE INCORPORATION OF ORGANIC MATTER AND MICROORGANISMS
}

\author{
Pedro J. Valarini ${ }^{1 *}$; M $^{\mathrm{a}}$ Cruz Díaz Alvarez²; José $\mathbf{M}^{\mathrm{a}}$ Gascó$^{2}$; Francisca Guerrero² ; Hasime Tokeshi $^{3}$
}

\begin{abstract}
${ }^{1}$ Embrapa Meio Ambiente, Centro Nacional de Pesquisa de Monitoramento e Avaliação do Impacto Ambiental, Jaguariúna, SP, Brasil; ${ }^{2}$ Departamento de Edafología de la E.T.S.I. Agrónomos, Universidad Politécnica, Madrid, España,

${ }^{3}$ Departamento de Fitopatologia, Escola Superior de Agricultura “Luiz de Queiroz”, Universidade de São Paulo, Piracicaba, SP, Brasil
\end{abstract}

Submitted: October 18, 2000; Returned to authors for corrections: January 22, 2002; Approved: February 25, 2002

\begin{abstract}
The soil quality was evaluated following the addition of organic matter and microorganisms to a clay loam soil collected in Aranjuez (Madrid) under controlled conditions of temperature and moisture, and over a period of three months. The following treatments were carried out: soil (control); soil $+50 \mathrm{t} / \mathrm{ha}$ of animal manure (E50); soil $+50 \mathrm{t} / \mathrm{ha}$ of animal manure $+30 \mathrm{l} / \mathrm{ha}$ of effective microorganisms $(\mathrm{E} 50 \mathrm{EM})$; soil $+30 \mathrm{t} / \mathrm{ha}$ of combination of various green crop residues and weeds (RC30) and soil $+30 \mathrm{t} / \mathrm{ha}$ of combination of various green crop residues and weeds $+301 /$ ha of effective microorganisms $(\mathrm{RC} 30 \mathrm{EM})$. The soil samples were taken before and after the incubation and analysed using physical, chemical and microbiological parameters. A significant increase in the production of polysaccharides and alkaline phosphatase and esterase enzymes in the treatments E50EM and RC30EM was observed, being in direct correlation with the humification of the organic matter, with the water retention at field capacity, and with the cationic exchange capacity (CEC). It can be concluded that the incorporation of microorganisms EM potentialized the soil biological activity and improved physicochemical soil properties, contributing to a quick humification of fresh organic matter. Those findings were proved by microbiological activities of exopolysaccharides by alcaline phosphatase and esterase enzymes, which can be used as earlier and integral soil health indicators.
\end{abstract}

Key words: methodology, organic matter, microorganisms, physico-chemical, microbiological soil properties

\section{INTRODUCTION}

In the last ten years, soil quality became a matter of awareness throughout the world. The current concept of soil quality includes different attributes such as: soil, plant and biological productivity, environmental quality and human and animal health.

As known, many currently used agricultural technologies and practices such as monocrops, residue management, mineral fertilization, overuse of pesticides, agricultural heavy machinery, inadequate management practices of the soil and irrigated water can significantly affect soil quality by changing the physical, chemical and biological properties of the soil (8). Besides, the low input of organic matter into the soil in conventional production systems has generated disbalances in the edaphic ecosystems, with a decrease in the microbial activities of mycorrhizas, endobacteria, and plant growth promoting rhizobacteria (PGPR). This effect contributes significantly to modify the plant growth by holding plant nutrition and by making plants more susceptible to pests $(1,12,15,28)$.

\footnotetext{
* Corresponding author. Mailing address: Laboratório de Microbiologia e Fitopatologia, Caixa Postal 69, 13820-000, Jaguariúna, SP, Brasil. Fax: (+5519) 3867-8740. E-mail: valarini@cnpma.embrapa.br
} 
Most researches in this subject have focused on the development of environmental quality indicators and soil management practices that restore and/or improve vegetal and biological production aiming at minimising negative environmental impacts (6), and contributing for the onset of a more sustainable agriculture (4). The use of animal manure, crop diversification and rotation, and application of biological control agents are appropriate practices recommended to restore and/or improve the quality of agricultural soils. Historically and until recently, chemical and physical properties have been used as crude measures of soil productivity. However, only a static type of data can be obtained in this way. Besides, organic matter content in soils changes very slowly over time, and therefore, many years may be required to detect changes in it caused by intensive agriculture or other sort of disturbances. As far back as 1916 (19), it was argued that a lower productive capacity in a soil was the result of a neglected microbiological functioning within that soil. Therefore, there is growing evidence that soil microbiological and biological parameters may possess potential as early and sensitive indicators for soil ecological stress or reparation $(3,4,5)$, as is the case of soil enzyme activities and exopolysaccharides, soil microbial biomass, composion of soil microflora, that were used as potential biochemical/biological indicators of soil quality $(4,8,9)$. The aim of this research was to develop an efficient and fast methodology that uses physical chemical and microbiological soil parameters integrated to evaluate the improvement of the soil quality results due the incorporating of different types and quantities of organic matter and species of microorganisms in a degraded soil.

\section{MATERIALS AND METHODS}

The efficiency of the incorporation of organic matter and microorganisms to a clay loam soil of green house production collected in Aranjuez (Madrid) was studied in controlled conditions of temperature and moisture, over a period of three months. The following treatments were used: a) soil (control); b) soil $+50 \mathrm{t} / \mathrm{ha}$ of animal manure (E50); c) soil $+50 \mathrm{t} / \mathrm{ha}$ of animal manure +30 1/ha of effective microorganisms (E50EM); d) soil $+30 \mathrm{t} / \mathrm{ha}$ of mixed fresh plant debris (Zea mays L. and Brussels sprout) and weeds (Elesione indica, Cynodon dactylon, Bromus commutatus) (RC30); and e) soil $+30 \mathrm{t} / \mathrm{ha}$ of mixed of various green crop residues and weeds +30 1/ha of EM (RC30EM). C/N of animal manure and mixed fresh plant debris and weeds (grass and vegetables) were 158,62 and 119,11, respectively. EM is a probiotic of beneficial microorganisms that can be applied as soil conditioners to increase the microbial diversity of soils and plants. It contains selected species of microorganisms originated from beer fermentation, soybean paste and yoghurt, including predominant populations of lactic acid bacteria (Lactobacillus plantarum and Streptococcus lactis) and smaller numbers of photosynthetic bacteria (Rhodopseudomonas capsulatus and Rhodobacter sphaeroides), actinomycets (Streptomyces albus), yeasts (Saccharomyces cerevisiae and Candida utilis) that accelerate the decomposition of the remaining vegetal material, increase the nutrients recycling and the atmospheric nitrogen fixation, faster nutrients solubilizing and improves proprieties $(17,22,27)$. The EM4 solution was prepared and activated in laboratory with the addition of sacarose plus water in the concentration $50 \mathrm{~g}$ of sacarose to 5 litres of distilled water. The total amount of this solution was added to $500 \mathrm{ml}$ of EM4 and kept in rest for 3-4 days. After that, the solution of EM for the treatments E50EM and RC30EM was applied twice to the soil which had been previously mixed with organic matter: one application was made just after this mixture was done and the other, 15 days after the first application, in quantities required to reach the soil field capacity. In all the other treatments, including the control, only distilled water was added to the soil, also respecting the field capacity limit (14).

Treated soil samples, in three replicates per treatment, were kept in laboratory conditions for one month. Afterwards, a 200 $\mathrm{g}$ sample of each replicate was incubated in a 500-ml Erlenmeyer at $25^{\circ} \mathrm{C}$ temperature and $70 \%$ of soil field capacity humidity, using the apparatus proposed by Guerrero (16) to simulate the aerobic activity of the microorganisms. This system is exposed to a flow of humid and $\mathrm{CO}_{2}$-free air, which passes through $\mathrm{NaOH}$, using phenolphthalein as indicator. The $\mathrm{CO}_{2}$ released from microorganisms was collected in $30 \mathrm{ml}$ of $\mathrm{NaOH} 0.2 \mathrm{~N}$. The $\mathrm{Na}_{2} \mathrm{CO}_{3}$ produced was precipitated with $20 \% \mathrm{BaCl}_{2}$ and the excess of $\mathrm{NaOH}$ quantified with $\mathrm{HCl} 0.2 \mathrm{~N}$, using phenolphthalein as indicator. During four weeks, $\mathrm{CO}_{2}$ release was quantified daily. Based on curves of the adjusted accumulated mineralization $\left(\mathrm{C}=\mathrm{k} \cdot \mathrm{t}^{\mathrm{m}}\right)$ and on the derived mineralization $\left(\mathrm{dc} / \mathrm{dt}=\mathrm{k} \cdot \mathrm{m} \cdot \mathrm{.}^{\mathrm{m}-1}\right)$, where $\mathrm{C}$ is the total carbon released, $\mathrm{t}$ is time, in days, and $k$ and $m$ are constants, the $r$ values were calculated (10). The $r$ value indicated the difference in the mineralization speed depending on the material added in the treatments. One month before the soil treatments and after the incubation period (three months of experiment), soil samples were characterized through the following physical, chemical and biological parameters: field capacity $(\% \mathrm{FC}), \mathrm{pH}$, electric conductivity (CE), cationic exchange capacity (CEC), soil texture, $\mathrm{C} / \mathrm{N}$ relationship, percentage of carbon: in total humic extract $(\% \mathrm{CEHT})$, in humic acid $(\% \mathrm{CAH})$ and in fulvic acid (\%CAF), and the index: $\% \mathrm{C}(\mathrm{EHT}) / \% \mathrm{C}$ org, $\% \mathrm{C}(\mathrm{EHT}) / \% \mathrm{C}(\mathrm{AH}), \% \mathrm{C}(\mathrm{AH} /$ $\% \mathrm{C}(\mathrm{AF})$, exopolysaccharides, alkaline phosphatases and esterases enzymatic activities $(7,13)$. Data were submitted to the mean comparative analysis (test of Tuckey, $\mathrm{p}<0.05$ ). Regression statistical analysis were performed for all the parameters analysed in the two periods (a month after the organic material was applied and at the end of the experiment, three months after the sowing). 


\section{RESULTS AND DISCUSSION}

Figs. 1 and 2 refer to total microbial activity $\left(\mathrm{CO}_{2}\right.$ released $)$ and accumulated mineralization curves $\left(\mathrm{C}=\mathrm{K} \cdot \mathrm{t}^{\mathrm{m}}\right)$ and equations of mineralization speed derivatives $\left(\mathrm{dC} / \mathrm{dt}=\mathrm{K} \cdot \mathrm{m} \cdot \mathrm{t}^{\mathrm{m}-1}\right)$, respectively. Daily mineralization curves (Fig. 1) follow a pattern similar to the classic exponential curve of microorganism development (25). Based on them, different phases can be observed: the first phase refers to an intensive mineralization during the first week of incubation, and a decrease in its intensity beginning on the seventh day; the second phase corresponds to reorganization and maintenance of an average mineralization activity until about the $30^{\text {th }}$ day; and the third phase is represented by an accentuated decrease in activity caused by limiting nutrition factors (16). Guerrero (16) also reported that during the growth phase, daily mineralization follows the derivation of the exponential curve for the population growth because respiration is dependent upon the number of microorganisms. However, during the decreasing phase (or third phase), the $\mathrm{CO}_{2}$ released is not directly dependent upon the number of microorganisms, but on other limiting factors such as nutrients. Mineralization in the decreasing phase is better adjusted to the derivative of the accumulated potential curve $\left(\mathrm{C}=\mathrm{K} . \mathrm{t}^{\mathrm{m}}\right)$. So, in Fig. 2 , it can be observed that all the accumulative curves of $\mathrm{CO}_{2}$ released due to biological activity are adjusted to the model significantly at the level of $99 \%$ probability (10). In this figure, the control is the treatment with the lowest biological activity, while treatments with biggest activities were mixtures of manure and crop remaining material with EM, E50EM and RC30EM, respectively.

Tables 1 and 2 show the physical, chemical and microbiological parameters determined in samples of the different treatments, one month after having mixed different types and quantities of organic matter with EM and at the end of the experiment (three months), respectively. The results clearly show that the $\mathrm{pH}$ decreased significantly in all treatments as compared with the control $(\mathrm{T})$, whereas the electric conductivity (CE) increased in all treatments (Table 1) except $\mathrm{RC} 30$ (control $=\mathrm{RC} 30$ ) treatment while after incubation, (Table 2), data of $\mathrm{pH}$ showed no significant differences between treatments, even though CE increased considerably in just in E50 and E50EM treatments all, which can be attributed to the organic matter mineralization. Oxidable organic carbon percentage $(\% \mathrm{C})$ of $\mathrm{T}$ remained steady during the experiment, increasing significantly after incubation in all the mixtures, due to the intensive humification of organic matter. Organic nitrogen percentage $(\% \mathrm{~N})$ showed an increase comparing to the earliest data, but a significant growth was noted only in the E50EM treatment. Also, the application of manure (50t/ha) influences significantly the content of the carbon and organic nitrogen $(\mathrm{C} / \mathrm{N})$ that benefited microbiological and biochemical activities as verified in the production augmentation of

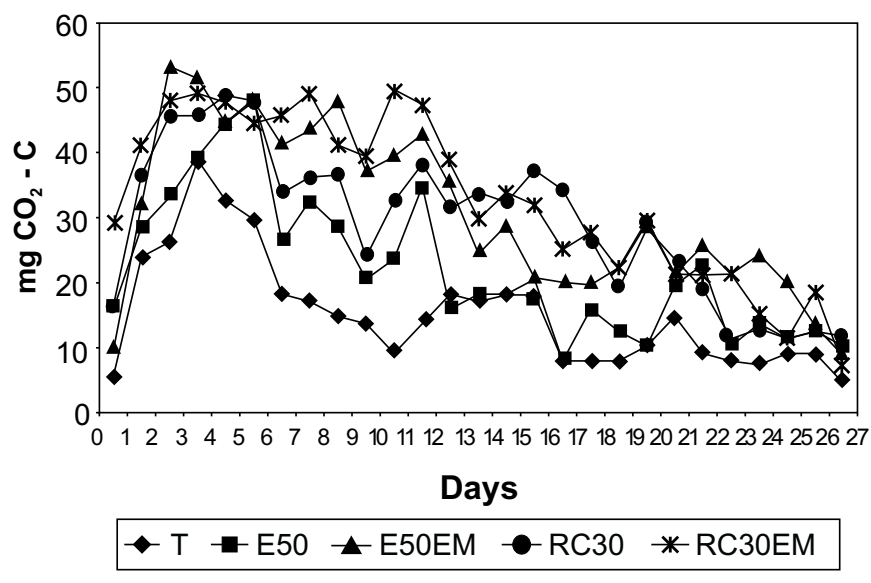

Figure 1. Determination of total microbial activity $\left(\mathrm{mg} \mathrm{CO}_{2}-\mathrm{C}\right)$ in sample of soil mixed with different types of organic matter, incubated at $25^{\circ} \mathrm{C}$.

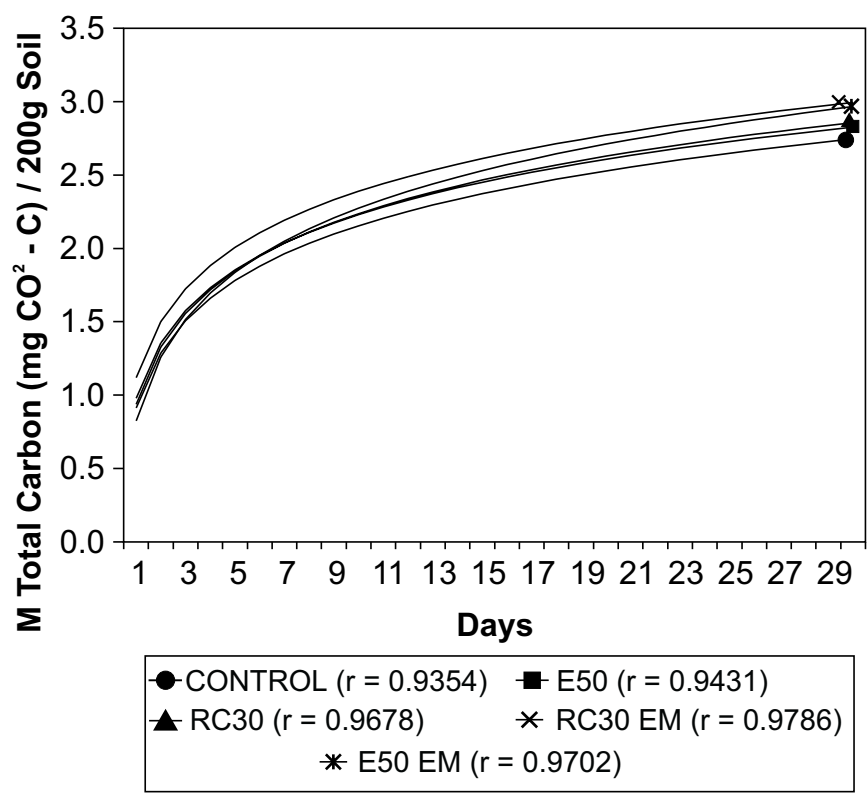

Figure 2. Mineralization of $\mathrm{C}$ accumulated to the soil samples added with different types and quantities of organic matter, incubated at $25^{\circ} \mathrm{C}$.

polysaccharides and phosphatase and esterase enzymes (Tables 1 and 2). Generally, the $\mathrm{C} / \mathrm{N}$ ratio is used as indicator for the evolution of the decomposition process of organic matter. According to Burés (2) accepted values for $\mathrm{C} / \mathrm{N}$ ratios range from 15 to 30 . Therefore, the $\mathrm{C} / \mathrm{N}$ values obtained in this assay with the treatments: RC30EM, E50 and E50EM are within the range above and consequently are adequate for the 
Table 1. Physical, chemical and microbiological characteristics of a soil with different kinds and quantities of organic matter, before incubation ${ }^{1}$.

\begin{tabular}{lccccc}
\hline \multicolumn{1}{c}{ Characteristics } & Control & RC30 & RC30EM & E50 & E50EM \\
\hline $\mathrm{pH}$ & $7.79 \mathrm{a}$ & $7.36 \mathrm{~b}$ & $7.43 \mathrm{~b}$ & $7.42 \mathrm{~b}$ & $7.39 \mathrm{~b}$ \\
$\mathrm{CE}\left(\mu \mathrm{S} / \mathrm{cm} \mathrm{a} 25^{\circ} \mathrm{C}\right)$ & $624 \mathrm{a}$ & $864 \mathrm{ab}$ & $1529 \mathrm{c}$ & $1200 \mathrm{bc}$ & $1476 \mathrm{c}$ \\
$\% \mathrm{C}$ & $1.49 \mathrm{a}$ & $1.69 \mathrm{a}$ & $1.72 \mathrm{a}$ & $1.54 \mathrm{a}$ & $2.04 \mathrm{~b}$ \\
$\% \mathrm{~N}$ & $0.15 \mathrm{a}$ & $0.21 \mathrm{a}$ & $0.21 \mathrm{a}$ & $0.3 \mathrm{~b}$ & $0.33 \mathrm{~b}$ \\
$\mathrm{C} / \mathrm{N}$ & $9.93 \mathrm{a}$ & $8.05 \mathrm{a}$ & $8.19 \mathrm{a}$ & $5.13 \mathrm{~b}$ & $6.18 \mathrm{~b}$ \\
$\% \mathrm{FC}$ & $22.98 \mathrm{a}$ & $25.03 \mathrm{~b}$ & $29.59 \mathrm{c}$ & $30.56 \mathrm{~cd}$ & $31.33 \mathrm{~d}$ \\
$\mathrm{CEC}$ & $13.74 \mathrm{a}$ & $14.6 \mathrm{a}$ & $14.43 \mathrm{a}$ & $15.65 \mathrm{a}$ & $16.43 \mathrm{~b}$ \\
$\% \mathrm{CEHT}$ & $0.528 \mathrm{a}$ & $1.028 \mathrm{~b}$ & $1.132 \mathrm{~b}$ & $1.019 \mathrm{~b}$ & $1.355 \mathrm{c}$ \\
$\% \mathrm{CAH}$ & $0.211 \mathrm{a}$ & $0.223 \mathrm{a}$ & $0.396 \mathrm{~b}$ & $0.602 \mathrm{c}$ & $0.756 \mathrm{~d}$ \\
$\% \mathrm{CAF}$ & $0.319 \mathrm{a}$ & $0.723 \mathrm{~b}$ & $0.736 \mathrm{~b}$ & $0.385 \mathrm{c}$ & $0.582 \mathrm{c}$ \\
$\% \mathrm{CEHT} / \% \mathrm{CAH}$ & $2.521 \mathrm{ab}$ & $4.161 \mathrm{c}$ & $2.926 \mathrm{~b}$ & $1.64 \mathrm{a}$ & $1.753 \mathrm{a}$ \\
$\% \mathrm{CEHT} / \% \mathrm{C}$ & $0.353 \mathrm{a}$ & $0.641 \mathrm{~b}$ & $0.677 \mathrm{~b}$ & $0.685 \mathrm{~b}$ & $0.664 \mathrm{~b}$ \\
$\% \mathrm{CAH} / \% \mathrm{CAF}$ & $0.669 \mathrm{a}$ & $0.316 \mathrm{a}$ & $0.519 \mathrm{a}$ & $1.564 \mathrm{~b}$ & $1.328 \mathrm{~b}$ \\
Alkaline Phosphatase & $66.54 \mathrm{a}$ & $125.76 \mathrm{~b}$ & $163.4 \mathrm{c}$ & $114.98 \mathrm{~b}$ & $127.08 \mathrm{~b}$ \\
Esterase & $35.1 \mathrm{a}$ & $60.24 \mathrm{c}$ & $81.45 \mathrm{c}$ & $47.97 \mathrm{~b}$ & $69.37 \mathrm{~d}$ \\
Polysaccharides & $0.039 \mathrm{a}$ & $0.062 \mathrm{~b}$ & $0.084 \mathrm{~b}$ & $0.119 \mathrm{c}$ & $0.134 \mathrm{c}$ \\
\hline
\end{tabular}

${ }^{1}$ One month after addition of organic matter in the soil. Average of three replication. Values in horizontal row followed by the same letter(s) are not significant different between themselves according to the Tuckey text $(\mathrm{P} \leq 0.05)$.

Table 2. Physical, chemical and microbiological characteristics of a soil with different kinds and quantities of organic matter, after incubation ${ }^{1}$.

\begin{tabular}{lccccc}
\hline \multicolumn{1}{c}{ Characteristics } & Control & RC30 & RC30EM & E50 & E50EM \\
\hline $\mathrm{pH}$ & $7.74 \mathrm{a}$ & $7.74 \mathrm{a}$ & $7.26 \mathrm{a}$ & $7.65 \mathrm{a}$ & $7.4 \mathrm{a}$ \\
$\mathrm{CE}\left(\mu \mathrm{S} / \mathrm{cm} \mathrm{a} 25^{\circ}\right.$ & $896 \mathrm{a}$ & $1283 \mathrm{a}$ & $1429 \mathrm{ab}$ & $3077 \mathrm{c}$ & $2339 \mathrm{bc}$ \\
$\% \mathrm{C}$ & $1.49 \mathrm{a}$ & $2.71 \mathrm{~b}$ & $3.76 \mathrm{c}$ & $3.67 \mathrm{c}$ & $4.32 \mathrm{~d}$ \\
$\% \mathrm{~N}$ & $0.2 \mathrm{a}$ & $0.24 \mathrm{a}$ & $0.29 \mathrm{a}$ & $0.3 \mathrm{a}$ & $0.33 \mathrm{~b}$ \\
$\mathrm{C} / \mathrm{N}$ & $7.45 \mathrm{a}$ & $10.29 \mathrm{a}$ & $12.96 \mathrm{~b}$ & $12.53 \mathrm{~b}$ & $12.34 \mathrm{~b}$ \\
$\% \mathrm{FC}$ & $24.57 \mathrm{a}$ & $25.71 \mathrm{a}$ & $34.21 \mathrm{c}$ & $31.28 \mathrm{~b}$ & $34.37 \mathrm{c}$ \\
$\mathrm{CEC}$ & $14.61 \mathrm{a}$ & $14.6 \mathrm{a}$ & $15.01 \mathrm{ab}$ & $16.42 \mathrm{bc}$ & $16.85 \mathrm{c}$ \\
$\% \mathrm{CEHT}$ & $0.981 \mathrm{a}$ & $1.358 \mathrm{~b}$ & $2.135 \mathrm{c}$ & $1.912 \mathrm{c}$ & $2.421 \mathrm{c}$ \\
$\% \mathrm{CAH}$ & $0.473 \mathrm{a}$ & $0.465 \mathrm{a}$ & $0.902 \mathrm{~b}$ & $1.145 \mathrm{c}$ & $1.432 \mathrm{~d}$ \\
$\% \mathrm{CAF}$ & $0.508 \mathrm{a}$ & $0.875 \mathrm{abc}$ & $1.151 \mathrm{c}$ & $0.796 \mathrm{ab}$ & $0.988 \mathrm{ac}$ \\
$\% \mathrm{CEHT} / \% \mathrm{CAH}$ & $2.074 \mathrm{a}$ & $2.871 \mathrm{~b}$ & $2.239 \mathrm{a}$ & $1.639 \mathrm{a}$ & $1.69 \mathrm{a}$ \\
$\% \mathrm{CEHT} / \mathrm{C}$ & $0.658 \mathrm{~b}$ & $0.519 \mathrm{a}$ & $0.565 \mathrm{a}$ & $0.507 \mathrm{a}$ & $0.581 \mathrm{a}$ \\
$\% \mathrm{CAH} / \% \mathrm{CAF}$ & $0.931 \mathrm{ab}$ & $0.54 \mathrm{a}$ & $0.807 \mathrm{a}$ & $1.564 \mathrm{~b}$ & $1.449 \mathrm{~b}$ \\
$\mathrm{Alkaline} \mathrm{Phosphatase}$ & $152.14 \mathrm{a}$ & $344.65 \mathrm{bc}$ & $394.11 \mathrm{c}$ & $320.09 \mathrm{~b}$ & $564.17 \mathrm{~d}$ \\
Esterase & $40.39 \mathrm{a}$ & $49.81 \mathrm{ab}$ & $92.37 \mathrm{c}$ & $59.6 \mathrm{ab}$ & $75.1 \mathrm{bc}$ \\
Polysaccharides & $0.257 \mathrm{a}$ & $0.707 \mathrm{~b}$ & $0.956 \mathrm{cb}$ & $0.89 \mathrm{bc}$ & $1.112 \mathrm{~d}$ \\
\hline
\end{tabular}

${ }^{1}$ Three months (one month after addition of organic matter plus two months of incubation). Average of three replication. Values in horizontal row followed by the same letter(s) are not significant different between themselves according to the Tuckey text $(\mathrm{P} \leq 0.05)$.

microorganisms to growth and sintesize proteins. This did not occur with the mixture of crop remaining fresh material with weeds (RC30 and RC30EM), which can be attributed to a smaller humification of this type of organic material. This was confirmed by the humificated fraction $(\% \mathrm{CAH})$ tendency, although in $\%$ CEHT it is clear the influence of both crop remaining material 
and manure. This result is better shown mainly by the \%CEHT/ $\% \mathrm{C}$ and $\% \mathrm{CAH} / \% \mathrm{CAF}$ indices, where higher values indicate higher humification rate and higher degree of polimeralization of the humificated fraction, respectively. According to FILIP (9), selected processes indicating the intensity of mineralization of organic matter should not fail when evaluating soil quality. Furthermore, the change in quantity and quality of soil organic matter, i.e., humic substances, can be indicative for agradative and/or degradative developments in a soil ecosystem.

Similar results occurred to the water retention capacity (\%FC), especially for manure and crop remaining material treatments (E50, E50EM and RC30EM). All the mixtures enhanced significantly $\% \mathrm{CF}$ when compared with the control (Table 1). The cationic exchange capacity (CEC) was influenced significantly only in the manure plus microorganisms treatment (E50EM) (Table 1) and E50 and E50EM treatments (Table 2) in relation to the control (T). Phosphatases alkaline, esterases and exopolysaccharides also revealed this significant trend, mainly, for the RC30EM and E50EM treatments, after incubation (Table 2). According to Sarmentero et al., (23), the activity of certain enzymes such as dehydrogenases is used to quantify the total microbial activity in a soil and a good relationship has been found between this procedure and other methods such as soil respiration. Thus, the hydrolisis of fluorescein diacetate is a more sensible and rapid proof than the dehydrogenase activity, showing that quantification of esterases represents an efficient indicator to evaluate the microbial activity in soils.

Significant correlation was observed between exopolysacharydes and alcaline phosphatase $(0.92 * *)$, exopolysaccharides and esterase $\left(0.79^{*}\right)$, and exopolysaccharides and CEC $\left(0.71^{*}\right)$, showing that some microbiological and physico-chemical parameters, taken together, may be sensitive indicators of improvements in structure and soil fertility, in a very short time. That is the case of exopolysaccharides (21), esterase enzyme activities (23) and CEC, as well as nutrients deliverance to plants during the organic matter mineralization process as for phosphatase (24) and exopolysaccharides (26). This result confirms that this investigation should be accompained by simultaneous determination of the basic physico-chemical soil chraracteristics such as $\mathrm{pH}, \mathrm{CEC}$, moisture content and temperature. These abiotic chraracteristics can allow a better understanding of the biological and biochemical data obtained and support the final evaluation of soil quality $(9,18,20)$. It is unlikely that a single absolute soil enzyme activity or any other biological measurement could be used to assess soil quality, because soils naturally vary widely in biological activity; also, soil enzyme activities have not consistently correlated to crop productivity. However, these parameters may only be used as components of an universal composed index that aggregates several key biological, chemical, and physical parameters for determining soil quality in relation to plant growth $(4,5,6,8)$.
Thus, considering that EM functions as an activator of soil microorganism populations and as an ameliorator of the physicochemical soil properties, accordingly with several authors $(11,17,27)$, it can be concluded that EM potentialized soil biological activity, contributing to a quick humification of fresh organic matter. As found in this work, this process can be monitored with the following microbiological and biochemical indicators: exopolysaccharides and alcaline phosphatase and esterase enzymes. It is also clear that those indicators are close related to certain physico-chemical indicators, such as: cationic exchange capacity (CEC) and, in a lower degree, field capacity (FC). These results agree with the findings obtained by other authors $(11,20,27,28)$. Finally, this method can contribute, in a shorter time, to elucidate changes occurred in the soil quality under field conditions, which can be also used to predict crop productivity.

\section{ACKNOWLEDGMENT}

The authors recognize the contributions of Dr. Clayton Campanhola, Researcher at Embrapa Environment for his careful review in the English version of this manuscript.

\section{RESUMO}

\section{Avaliação integrada da qualidade do solo após a incorporação de matéria orgânica e microrganismos}

A qualidade do solo foi avaliada após a incorporação de matéria orgânica e microrganismos eficazes (EM) em solo franco argiloso coletado em cultivos protegidos em Aranjuéz (Madrid). Os tratamentos constaram de solo (controle); solo +50 ton./ha de esterco de animal (E50); E50 + EM (E50EM); solo + 30 ton/ha de restos de cultivos + plantas invasoras (RC30); RC30 + 301/ha EM (RC30EM). Amostras de solo dos tratamentos foram tomadas após o tratamento, antes e após a incubação e analisadas usando os parâmetros físico-químicos e microbiológicos. Observou-se aumento significativo na produção de polissacarídeos, nas atividades enzimáticas esterases e fosfatases alcalina principalmente, nos tratamentos E50EM e RC30EM, sendo diretamente correlacionadas com a humificação da matéria orgânica, com a capacidade de campo e com a capacidade de intercâmbio catiônico. A partir desses resultados, pode se concluir que o solo tratado com microrganismos eficazes teve intensa atividade biológica, contribuindo para uma mais rápida humificação da matéria orgânica fresca e melhorando as propriedades fisico-química do solo, destacando os parâmetros microbiológicos como indicadores precoces de recuperação da qualidade do solo.

Palavras-chave: metodologia, matéria orgânica, propriedades fisico-químicas e microbiológicas do solo, microrganismos 


\section{REFERENCES}

1. Agrawal, A.A.; Tuzun, S.; Bent, E. Induced plant defenses against pathogens and herbivores. Biochemistry, ecology and agriculture. APS Press, St. Paul, 1999, 390p.

2. Burés, S. Sustratos. Ediciones Agrotécnicas J.L., Madrid, 1997, 342p.

3. Dick, R.P. A review: long-term effects of agricultural systems on soil biochemical and microbial parameters. Agric. Ecosyst. Environ., 40: 25-60, 1992.

4. Dick, R.P. Soil enzyme activities as indicators of soil quality. In: Doran, J.W.; Coleman, D.C.; Bezdicek, D.F.; Stewart, B.A. (eds). Defining soil quality for a sustainable environment. Minneapolis, Soil Science Society of America, 1994, p.107-124. (SSSA Special Publication, 35).

5. Dilly, O.; Blume, H.P. Indicators to assess sustainable land use with reference to soil microbiology. Adv. GeoEcol., 31: 29-36, 1998.

6. Doran, J.W.; Parkin, J.B. Defining and assessing soil quality. In: Doran, J.W.; Coleman, D.C.; Bezdicek, D.F.; Stewart, B.A. (eds). Defining soil quality for a sustainable environment. Minneapolis, Soil Science Society of America, 1994, cap.1, p.3-22. (SSSA Special Publication, 35).

7. EMBRAPA. Serviço Nacional de Levantamento e Conservação de Solos. Manual de métodos de análise de solo. 2.ed. EMBRAPA, Rio de Janeiro, 1997, 212p. (EMBRAPA-CNPS. Documentos, 1).

8. Fauci, M.F.; Dick, R.P. Microbial biomass as an indicator of soil quality: effects of long-term management and recent soil amendments. In: Doran, J.W.; Coleman, D.C.; Bezdicek, D.F.; Stewart, B.A. (eds). Defining soil quality for a sustainable environment. Minneapolis, Soil Science Society of America, 1994, cap.17, p.229-234. (SSSA Special Publication, 35).

9. Filip, Z.K. Soil quality assessment: an ecological attempt using microbiological and biochemical procedures. Adv. GeoEcol., 31: 2127, 1998

10. Fisher, A.R.; Yates, F. Statistical tables for biological, agricultural and medical research. 6.ed. Oliver and Boyd, Edimburgh, 1963, table VII, p.63.

11. Frighetto, R.T.S.; Valarini, P.J.; Tokeshi, H.; Oliveira, D.A. Action of effective microorganisms EM on microbial, biochemical and compaction parameters of sustainable soil in Brazil. V International Conference on Kyusei Nature Farming, Bangkok, Thailand, 1997, p.159-164.

12. Frighetto, R.T.S.; Valarini, P.J.; Tokeshi, H.; Filizola, H.F.; Felipe, A.; Oliveira, D.A. Effects of management practices on soil physicochemical, biochemical and microbial parameters under irrigated agriculture. Conferência Internacional IFOAM 98, 1998, S 9, n.158.

13. Frighetto, R.T.S.; Valarini, P.J. Indicadores biológicos e bioquímicos da qualidade do solo: manual técnico. Embrapa Meio Ambiente, Jaguariúna, 2000, 198p. (Embrapa Meio Ambiente. Documentos, 21).

14. Fundação Mokiti Okada. Experimentos sobre o uso dos microrganismos eficazes (EM) no Brasil. III International Conference on Kyusei Nature Farming, Santa Barbara, Califórnia, 1993, p.190-192.
15. García, C.; Hernandez, T.; Costa, F.; Ceccanti, B. Biochemical parameters in soils regenerated by the addition of organic wastes. Waste Manage. Res., 12: 457-466, 1994.

16. Guerrero, F. Estudio de las propiedades físicas y químicas de algunas turbas españolas y su posible aprovechamiento agricola. Madrid, 1989, 234p. (Tesis Doctoral, Universidad Autonoma de Madrid).

17. Hussain, T.; Javaid, T.; Parr, J.F.; Jilanoi, G.; Haq, M.A. Rice and wheat production in Pakistan with effective microorganisms. Am. J. Alter. Agric., 14: 30-36, 1999.

18. Kumar, K.; Goh, K.M. Crop residues and management practices: effects on soil quality, soil nitrogen dynamics, crop yield and nitrogen recovery. Adv. Agron., 68: 97-279, 2000.

19. Lipman, J.G.; McLean, H.; Lint, H.C. Sulphur oxidation in soils and its effect on the availability of mineral phosphatases. Soil Sci., 1: 533-539, 1916.

20. Mäder, P.; Pfiffner, L.; Fliessbach, A.; von-Lützow, M.; Munch, J.C. Soil ecology- Impact of organic and conventional agriculture on soil biota and its significance for soil fertility. V International Conference On Kyusei Nature Farming, Bangkok, Thailand, 1997, p. 24-40.

21. Piccolo, A. Humus and soil conservation. In: Piccolo, A. (ed). Humic substances in terrestrial ecosystems. Elsevier Applied Science, Amsterdam, 1996, p.225-264.

22. Sakurai, M. Co-existence of photosynthetic bacterias streptomyces and lactic acid bacteria in solutions of effective microorganisms. V International Conference on Kyusei Nature Farming, Bangkok, Thailand, 1997, p.379-385.

23. Sarmentero, J.P.; Molina, A.; Colmenares, R. Influencia del abonado con compost y fertilizantes solubles sobre la actividad enzimática del suelo y la calidad del cultivo avena-veza en una finca de la alta montaña madrileña. I Cong. de la Soc. Española de Agricultura Ecológica, Toledo, 1994, p.47-56.

24. Speir, T.W.; Ross, D.J. Soil phosphatase and sulphatase. In: Burns, R.G. (ed). Soil enzymes. Academic Press, New York, 1978, p.197250 .

25. Steven, A. Studies on tropical soil microbiology: I. The evolution of carbon dioxide from the soil and bacterial growth curve. Soil Sci. 37: 109-115, 1934.

26. Stevenson, F.J. Humus chemistry: genesis, composition, reaction. J. Wiley \& Sons, N. York, 1982

27. Tokeshi, H.; Alves, M.C.; Sanches, A.B.; Harada, D.Y. Control of Sclerotinia sclerotiorum with effective microorganisms. Summa Phytopathol., 23: 146-154, 1997.

28. Valarini, P.J.; Frighetto, R.T.S.; Tokeshi, H.; Scramin, S.; Silveira, A.P.D.; Valarini, M.J.; Oliveira, D.A. Physico-chemical and microbiological properties of soil as affected by irrigated agricultural systems. In: Foguelman, D.; Lockeretz, W. (eds). Organic agriculture the credible solutionfor the XXI ${ }^{\text {st }}$ Century: proc. of the $12^{\mathrm{a}}$ Intern. IFOAM Scientific Conference, Mar del Plata, 1999, p. $165-171$. 